\title{
Análise multitemporal do uso e cobertura do manancial alagados e de seu entorno na região de Ponta Grossa-PR
}

\author{
Multitemporal analysis of the land use and land cover of the alagados water source and its \\ surrounding area in Ponta Grossa-PR.
Charles Andrey da Silva ', Paulo Costa de Oliveira Filho², Kelly Geronazzo Martins ${ }^{3}$ \\ ' Engenheiro Ambiental pela Universidade Estadual do Centro- Oeste- UNICENTRO-PR \\ 2,3 Departamento de Engenharia Ambiental da Universidade Estadual do Centro-Oeste - UNICENTRO-PR
}

\begin{abstract}
Resumo
Este estudo objetivou a análise multitemporal em dez anos (2001 a 2011) do uso e cobertura do manancial Alagados, que abastece a cidade de Ponta Grossa e seu entorno na faixa de $1 \mathrm{~km}$, enfocando a situação da faixa de 100 metros a partir da margem, de área de preservação permanente (APP). O manancial é uma das principais fontes de abastecimento de água da cidade de Ponta Grossa e o uso e ocupação do seu entorno pode acarretar danos ambientais e deterioração da qualidade da água. Utilizou-se imagens orbitais de resolução espacial média (30 metros) e a técnica de classificação orientada ao objeto precedida de segmentação de imagens. Os resultados demostraram que houve uma sensível redução na superfície do espelho d'água em 13,43\% (88,15 ha) no período de 2001 a 2011, o que evidencia grande assoreamento em determinados locais do reservatório, especificamente nas regiões de entrada dos rios Pitangui, Jotuba e Moquém, principais tributários da microbacia. Também foram detectadas mudanças na faixa de domínio de APP de 100 metros do entorno do reservatório, que comprovam um processo de degradação devido principalmente a um aumento na ocupação por edificações e agricultura.
\end{abstract}

Palavras-chave: Sensoriamento remoto, contaminação da água, assoreamento, reservatório de manancial.

\begin{abstract}
This study aimed the multitemporal analysis of land use and coverage of the water supply, Alagados and its surroundings ( $1 \mathrm{~km}$ range) in Ponta Grossa city over ten years (from 2001 to 2011). Especially attention was laid on the marginal areas (100 m range) of the permanent preservation areas (PPA). As the major water suply source of Ponta Grossa city, deterioration of water quality of Alagados is threatened by the misuse and disorderly occupation of its surroundings. We used satellite images of medium spatial resolution (30 meters) and the object oriented image method preceded by the image segmentation as the classification techniques. The results showed that there was a significant reduction in the surface of the water surface in $13.43 \%$ ( $88.15 \mathrm{ha}$ ) in the period 2001 to 2011, which shows a high sedimentation process occurred in certain areas of the reservoir. Changes were also detected in the PPA range domain (100 meters) surrounding the reservoir, confirming a degradation process due mainly to the increase buildings occupations and agricultural practices.
\end{abstract}

Keywords: Remote sensing, water pollution, sedimentation, reservoir watershed. 


\section{INTRODUÇÃO}

Alterações significativas na qualidade da água são, em grande parte, ocasionadas pela ocupação de mananciais. Tais alterações ocorrem, principalmente, devido a esgotos, sejam domésticos ou industriais, atividades rurais, que tenham presença de agrotóxicos ou dejetos provenientes da criação de animais (SANEPAR, 1999).

No manejo e gestão destas áreas é necessária uma atenção especial para as faixas de preservação permanente (APPs), constituídas principalmente por florestas ciliares. Estes ambientes de alta fragilidade e complexidade ecológica prestam uma série de serviços ecossistêmicos, como retenção de sedimentos, reciclagem de nutrientes e eliminação de substâncias contaminantes (GALVÃO \& AUGUSTIN, 2011).

O Conselho Nacional do Meio Ambiente - CONAMA, na Resoluções 302 e 303/2002, que dispõe sobre os parâmetros, definições e limites de Áreas de Preservação Permanente (APPs) de reservatórios artificiais e o regime de uso de seu

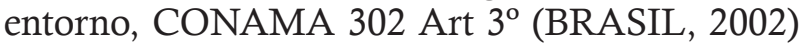
considera área de preservação permanente com largura mínima, em projeção horizontal, no entorno dos reservatórios artificiais, medida a partir da cota máxima normal de operação do reservatório, uma largura de $30 \mathrm{~m}$ para reservatórios artificiais situados em áreas urbanas e de $100 \mathrm{~m}$ para áreas rurais.

Alagados foi o nome dado para a área inundada pelo represamento do rio Pitangui, com finalidade de construção da barragem em 1929, para geração de energia. Em 1977, através de convênio, a COPEL liberou à SANEPAR a captação de água dessa represa para abastecimento da cidade. Alagados é responsável por aproximadamente $38 \%$ do abastecimento de água à cidade de Ponta Grossa (UEPG, 2002).

Com a construção da barragem e por consequência da formação do lago, a população passou a se interessar pela região, o que levou à construção de algumas casas em torno do lago, ainda na década de 40, sendo que em 1951 foi fundado o Ponta Grossa Iate Clube. Atualmente a área conta com mais de 150 construções residenciais somente a orla sul, que é pertencente ao município de Ponta Grossa. As construções são desprovidas de qualquer infraestrutura básica como esgoto e coleta de lixo, possibilitando agressão à zona de preservação (UEPG, 2002). Além disso, atividades agrícolas que são desenvolvidas no seu entorno (até $100 \mathrm{~m}$ da margem), como cultivo de milho, trigo e soja, o que pode comprometer a qualidade das águas.
Impactos devido ao uso inadequado do solo e da água, tanto em áreas rurais, urbanas e artificiais, são em sua maioria provocados por desmatamentos, erosão, poluição e contaminação de lençóis freáticos e demais corpos d'água, além do frequente acúmulo de materiais tóxicos e/ou nocivos que trazem grandes consequências à saúde humana e aos demais seres vivos (SILVA, 2003). Nesse contexto, as técnicas de processamento digital de imagens de sensoriamento remoto podem ser utilizadas para identificar, extrair, condensar e realçar as informações de mudanças no uso do solo (CROSTA, 1992).

Moro et al. (2004) utilizou fotografias aéreas verticais para verificar alterações de uso e ocupação da terra num período de aproximadamente 20 anos (1980 a 2001), ao longo da faixa de APP $(100 \mathrm{~m}) \mathrm{da}$ represa Alagados, obtendo os seguintes resultados: como impactos negativos, ocupação antrópica com casas de veraneio às margens da represa (poluição), aumento da silvicultura nas proximidades da barragem (contaminação biológica), aumento da área agrícola (erosão, assoreamento). E impacto positivo pelo aumento de áreas florestais, mais devido ao fato de serem áreas improdutivas deixadas ao processo natural de sucessão, do que pela conscientização ambiental ou respeito à legislação.

Cruz et al. (2009) mapearam o uso da terra no entorno da Represa de Salto Grande no município de Americana (SP), em uma distancia de 50 metros da margem, área de preservação permanente (APP) conforme Legislação Estadual de São Paulo, utilizando fotografias aéreas em escala 1:30.000. Os resultados desse trabalho indicaram que $86 \%$ da área correspondente à faixa de APP está com uso e ocupação em situações inadequadas.

Oliveira et al. (2008) verificaram a evolução da paisagem no entorno da Represa dos Rios Jaguari e Jacareí no estado de São Paulo, utilizando imagens de média resolução espacial dos satélites LANDSAT5/TM e CBERS-2/CCD no período de 1984/1985 e 2006 e detectaram um aumento das classes floresta nativa, floresta plantada e área urbana.

O presente estudo objetivou uma análise multitemporal do uso e cobertura em dez anos (2001 a 2011) do Manancial Alagados e de seu entorno em faixa de $1 \mathrm{~km}$ a partir da margem em dois períodos (2001 e 2011), incluindo a faixa de 100 metros de APP. 


\section{MATERIAL E MÉTODOS}

\section{I Caracterização e Localização da Área de EsTUDO}

A represa de Alagados (Figura 01) está localizada na Bacia Hidrográfica do Rio Tibagi e abrange parte dos municípios de Ponta Grossa, Castro e Carambeí. Com uma área de aproximada $380 \mathrm{~km}^{2}$, situa-se entre o meridiano $50^{\circ} \mathrm{W}$ e o paralelo $25^{\circ} \mathrm{S}$, seus principais tributários são os rios Pitangui e Jotuba (GOULART, 2001).

Conforme a classificação de Köeppen, a região apresenta clima Subtropical Úmido (Meso- térmico) $\mathrm{Cfb}$, com temperatura média do mês mais frio inferior a $18^{\circ} \mathrm{C}$, temperatura do mês mais quente inferior a $22^{\circ} \mathrm{C}$ tendo inexistência de estação seca definida. Segundo UEPG (2002), o período mais seco é dos meses de junho/julho/agosto, com total médio de 250 a $350 \mathrm{~mm}$ e o período mais chuvoso é de dezembro/janeiro/fevereiro, com total médio de 500 a $600 \mathrm{~mm}$. O total anual de precipitação oscila de 1.400 a $1.600 \mathrm{~mm}$.

A região fitoecológica é caracterizada pela Floresta Ombrófila Mista e Estepe Gramíneo-lenhosa (IBGE, 1992). A bacia de Alagados abrange quase totalmente o Primeiro Planalto Paranaense, tendo apenas como Segundo Planalto sua borda Leste e caracteriza-se por um relevo que varia de

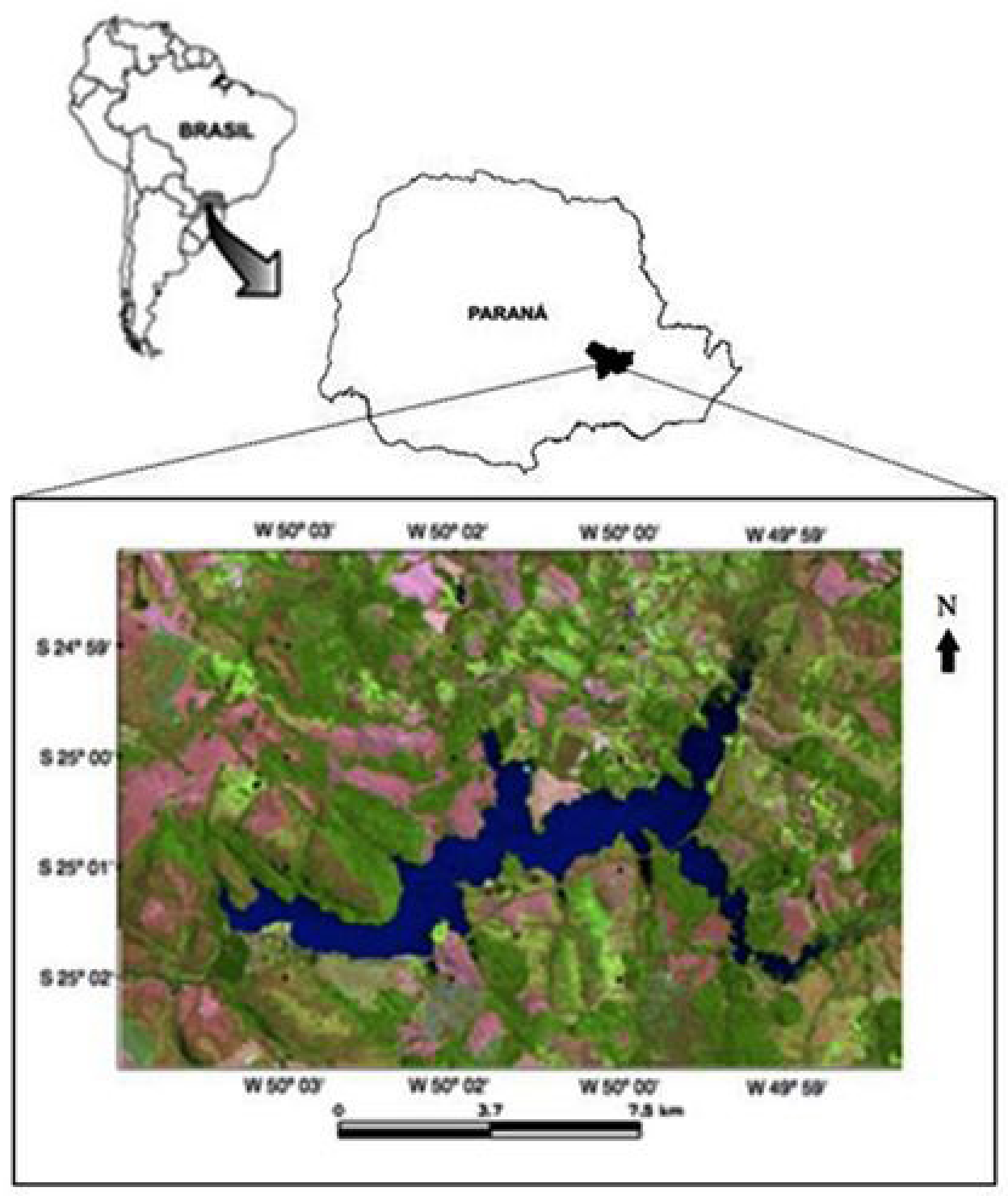

Figura 01.Localização do Reservatório de Alagados/Paraná e de seu entorno. 
suavemente ondulado a Morro, cujas maiores alturas chegam a mais de 200 metros (UEPG, 2002).

\subsection{Metodologia}

Inicialmente foi implementada a base cartográfica da área do estudo a partir das cartas topográficas planaltimétricas coloridas, em escala 1:50.000, obtidas pelo site do ITCG - Instituto de Terras Cartografia e Geociências do Estado do Paraná em formato digital matricial. Foram utilizadas quatro cartas identificadas pelas seguintes nomenclaturas: MI2824-4, MI2825-3, MI2840-2, MI2841-1. A seguir, as cartas foram importadas para o aplicativo SPRING versão 5.1.8 (CAMARA, 1996) a ser utilizado, recortadas para redimensionamento da área de trabalho e georreferenciadas.

Foram também utilizadas imagens do satélite LANDSAT-5 sensor TM com resolução espacial de 30 metros com data de 16-10-2001 e 06-062011, órbita 221 ponto 077, obtidas no sítio do INPE - Instituto Nacional de Pesquisas Espaciais. $\mathrm{Na}$ sequência foi realizado o registro das bandas de imagem 1, 2, 3, 4, 5 e 7 utilizando como base para a obtenção de pontos de controle, as cartas topográficas. Em ambas as imagens, foi elaborado um buffer zone, delimitando a faixa de $1 \mathrm{~km}$ e reduzindo a dimensão dos dados para uma área de $38,91 \mathrm{~km}^{2}$. A faixa de $100 \mathrm{~m}$ a partir da margem do reservatório para a delimitação da APP de seu entorno foi também demarcada.

Com o aplicativo SPRING versão 5.1.8 (CAMARA, 1996), foram utilizadas técnicas de realçamento e classificação por segmentação de imagens para mapear o uso e cobertura da terra no entorno do reservatório em ambas as épocas (2001 e 2011). A escolha da segmentação utilizada no processo de classificação foi definida através de vários testes, atribuindo diferentes valores aos parâmetros "limiar de similaridade" e "área mínima", aplicados ao processo de segmentação das imagens.

Foi realizado intenso trabalho de campo com uso de aparelho receptor de GPS de navegação marca Garmin modelo eTrex Vista $\mathrm{H}$ e máquina fotográfica digital para a definição das categorias utilizadas no processo de classificação. Imagens orbitais das séries históricas (2001 e 2011) de alta resolução do aplicativo Google Earth, além de mosaico de ortofotos colorido normal em escala de 1:50.000 de 2001, foram utilizados como verdade terrestre para complementar os trabalho de campo.

Para afastar a possibilidade de que variações de pluviosidade total dos meses de junho e outubro mascarassem o efeito do uso do solo na lamina d'água, foi efetuada uma análise de correlação de Spearman com 5\% de significância (ZAR, 1999). A análise foi calculada mediante a matriz dos valores de pluviosidade total entre os meses de junho e outubro de 2001 até 2011, cedidos pela estação de Ponta Grossa do SIMEPAR.

\section{RESULTADOS E DISCUSSÃO}

A correlação de Espearman, foi significativa (rSpearman $=0,59 ; \mathrm{P}=0,05)$, o que demostra que não existem oscilações sazonais siginificativas entre a pluviosidade total dos meses de junho e outubro para um intervalo de 10 anos (2001 até 2011).

Como resultados do trabalho realizado em campo e também com base na pesquisa bibliográfica, foram definidas e caracterizadas as seguintes classes para a região de estudo: "corpo d'água", "campos secos e rochosos", "florestas", "agricultura", "edificações", "reflorestamento" e "campos

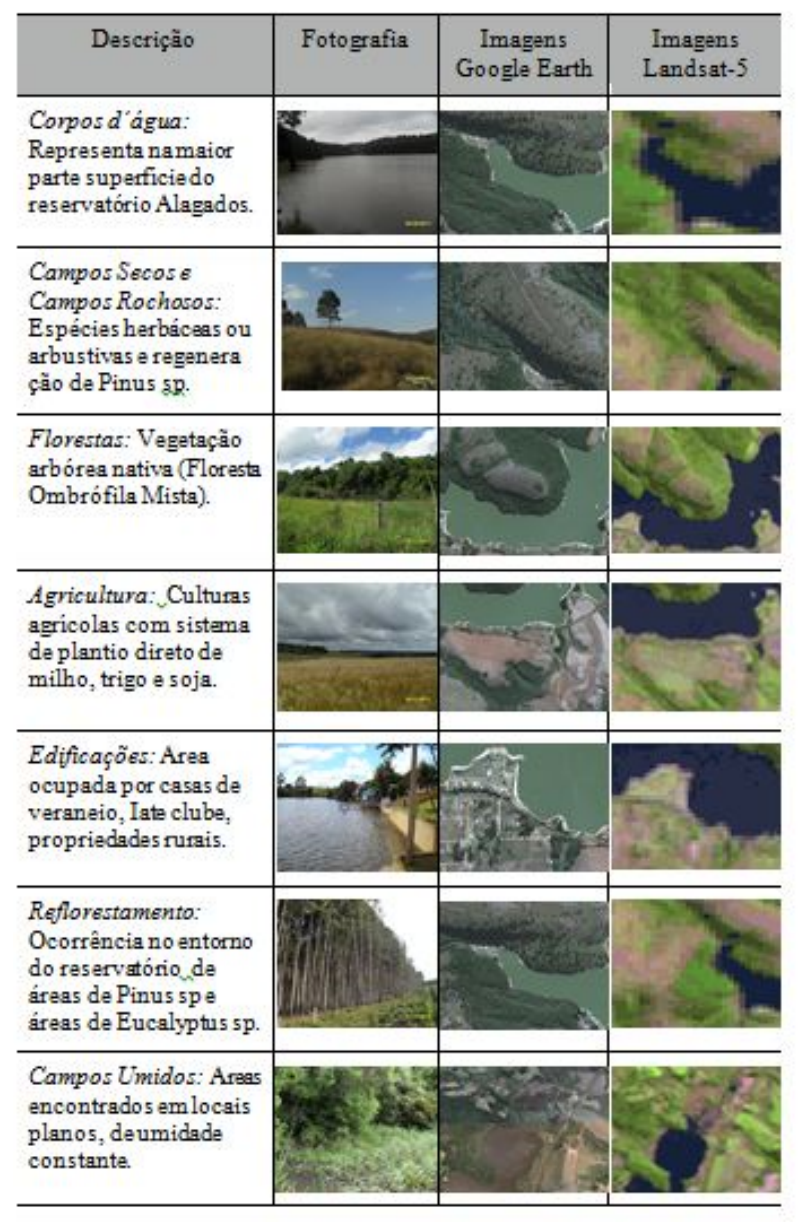

Figura 02. Descrição das classes definidas de uso e ocupação do solo do Reservatório de Alagados/Paraná. 

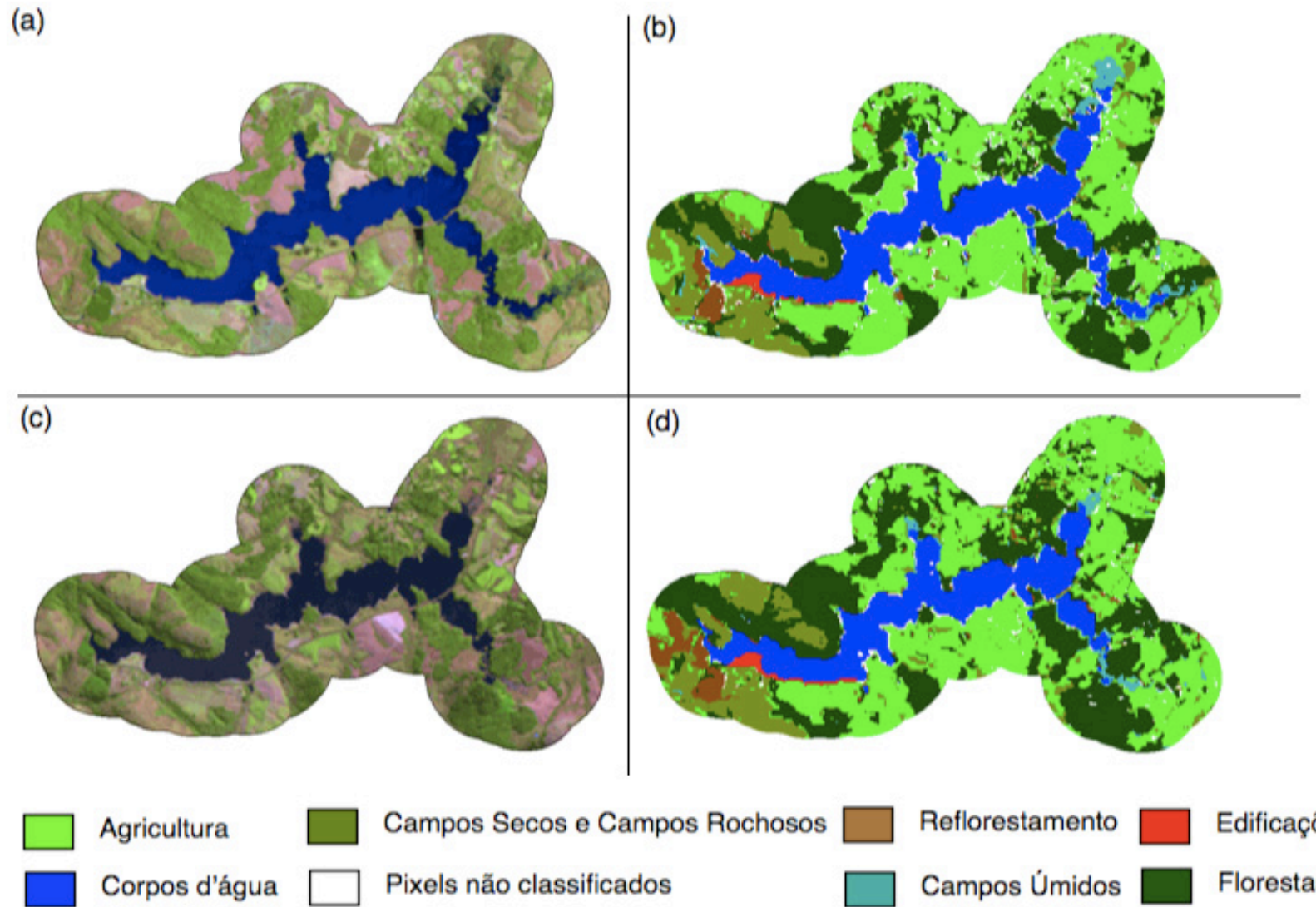

Reflorestamento

Edificações

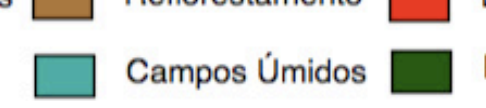

Florestas

Figura 03. Composição colorida 2001 (a), classificação 2001

(b), composição colorida 2011 (c) e classificação 2011 (d) de uso e ocupação do solo do Reservatório de Alagados/Paraná.

úmidos". Estão apresentados na Figura 02, a descrição de campo das classes de uso e ocupação da terra, fotografias terrestres e segmentos de imagem representando a assinatura espectral de cada classe nas imagens do Google Earth e na composição colorida do LANDSAT-5/TM elaborada com as bandas 5,4 e 3 respectivamente alocadas aos canais R, G e B (R5G4B3).

O estudo multitemporal de uso e cobertura da terra através das imagens satelitárias de resolução média do entorno do manancial Alagados permitiu avaliar o estado de conservação desta área no período de dez anos.

Os parâmetros utilizados para a segmentação de imagens que demonstraram melhores resultados foram respectivamente 15 para limiar de similaridade e 25 para área mínima para as imagens de 2001. Já para as imagens de 2011 foram usados 12 para limiar de similaridade e 25 para área mínima. O classificador utilizado foi o algorítmo de Bhattacharya definido $99 \%$ de probabilidade para aceitação. A Figura 03 apresenta as composições e respectivas classificações nos anos 2001 e 2011.

A Tabela 01 apresenta os resultados de área e percentual de uso e cobertura da terra na faixa de $1 \mathrm{~km}$ do entorno do manancial Alagados para as imagens de 2001 e 2011.

Os resultados observados na Tabela 02 indicam que para a área total abrangida de 3.891,24 ha, houve um aumento em $28,23 \%$ das áreas de edificações ( 4,19 ha). Nas áreas de florestas nativas, houve aumento de $18,76 \%$ (185,71 ha), possivelmente devido à regeneração natural da vegetação, e também a uma maior fiscalização ambiental nos últimos anos. As áreas de reflorestamento aumentaram sensivelmente em 72,07\% (44,29 ha). Constatou-se um recuo de $0,87 \%$ (13,18 ha) das áreas de agricultura, da mesma forma, de $6,17 \%(26,84$ ha) nas áreas campos secos e campos rochosos e também um recuo de $24,65 \%$ (21,36 ha) nas áreas de campos úmidos.

Foi detectada uma redução na superfície do espelho d'água do reservatório em $13,43 \%$ ( 88,15 ha), o que indica grande assoreamento em alguns locais. Para a classe "pixels não classificados" verifica-se nas imagens de 2001 e 2011 que, principalmente nas margens do reservatório, uma faixa estreita de pixels não se enquadrou em nenhuma das classes pré-definidas, provavelmente em função da alta frequência espacial nessa faixa de transição entre 
Tabela 01. Uso e cobertura da terra na faixa de $1 \mathrm{Km}$ do entorno do manancial Alagados/Paraná para imagens de 2001 e 2011

\begin{tabular}{l|c|c|c|c}
\hline \multicolumn{1}{c|}{ Classe } & Área em out/2001 (ha) & $\begin{array}{c}\text { Área em jun/2011 } \\
\text { (ha) }\end{array}$ & $\begin{array}{c}\text { \% } \\
\text { Aumento }\end{array}$ & $\begin{array}{c}\text { Recuo } \\
\text { Agricultura }\end{array}$ \\
\hline Corpos d'água & 656,55 & 1497,29 & & 0,87 \\
\hline $\begin{array}{l}\text { Campos Secos } \\
\text { e Campos } \\
\text { Rochosos }\end{array}$ & 434,77 & 568,40 & & 13,43 \\
\hline Florestas & 989,87 & 407,93 & & 6,17 \\
\hline Edificações & 14,84 & 1175,58 & 18,76 & \\
\hline Reflorestamento & 61,45 & 19,03 & 28,23 & \\
\hline Campos Úmidos & 86,69 & 105,74 & 72,07 & \\
\hline $\begin{array}{l}\text { Pixels não } \\
\text { classificados }\end{array}$ & 136,60 & 65,33 & & \\
\hline Total & $\mathbf{3 8 9 1 , 2 4}$ & 51,94 & & \\
\hline
\end{tabular}

o espelho d'água do reservatório e as demais classes de uso e ocupação do entorno.

Estas limitações estão relacionadas à resolução das imagens e também ao limiar de aceitabilidade definido na classificação.

O limiar de aceitabilidade assumido (99\%) resultou em regiões não classificadas nas imagens. Conforme (INPE, 2008), um limiar definido em $100 \%$ classificaria todos os pixels da imagem, mas provavelmente incluiria mais erros na classificação.

A Tabela 02 apresenta os valores obtidos para uso e cobertura apenas dentro dos limites definidos para APP do reservatório para os anos de 2001 e 2011 em área, em percentual e os percentuais de aumento e recuo das classes no período estudado.

Os resultados demostram que da área total de 1.024,61 ha abrangida pelo reservatório e APP, houve aumento das áreas de edificações em 33,39\% (4,26 ha) provavelmente devido à ocupação irregular destas áreas, com instalações às margens do reservatório em situação conflitante com a legislação.

Em relação à agricultura, havia 55,7 ha, para a mesma região, no período de 1980 a 2001.

Também se verificou um aumento das áreas de floresta nativa em 31,69\% (34,49 ha), provavelmente devido ao desenvolvimento dos estágios iniciais de floresta e à mudança da legislação, que ocorreu por ocasião da resolução 302/02 do
CONAMA, ampliando a faixa de APP em reservatórios.

Foi verificado um aumento das áreas de campos úmidos 29,47\% (12,09 ha) neste período de tempo, o que pode ser explicado pela redução do nível do reservatório. As áreas de campos secos e campos rochosos tiveram aumento em $14,66 \%$ (4,3 ha). Houve recuo das áreas de reflorestamento em 22,74\% (3,53 ha). Constatou-se também uma diminuição do espelho d'água do reservatório em $13,20 \%$ (86,29 ha), que evidencia a ocorrência de assoreamento acentuado no período estudado.

Desta forma, foi possível verificar que o maior conflito existente com a Resolução 302/02 do CONAMA, e que pode afetar a qualidade do manancial, está nas classes "edificações" e "agricultura", que demonstraram um crescimento dentro das faixas de domínio de 100 metros da APP do reservatório. A classe de edificações teve aumento devido à legislação pertinente não ter fiscalização rigorosa e ser um longo processo para efetuar a desapropriação dos imóveis situados nessa faixa da APP.

O aumento das áreas agrícolas nas proximidades das margens do reservatório pode ocasionar a erosão e consequentemente assoreamento, aliado ao enriquecimento das águas por nutrientes como nitrogênio e fósforo devido o uso de fertilizantes 
Tabela 02. Uso e cobertura na faixa de $100 \mathrm{~m}$ do entorno do manancial Alagados/Paraná para imagens de 2001 e 2011

\begin{tabular}{l|c|c|c|c}
\hline \multicolumn{1}{c|}{ Classe } & $\begin{array}{c}\text { Área em } \\
\text { out/2001 (ha) }\end{array}$ & $\begin{array}{c}\text { Área em jun/2011 } \\
\text { (ha) }\end{array}$ & $\begin{array}{c}\text { \% } \\
\text { Aumento }\end{array}$ & $\begin{array}{c}\text { \% } \\
\text { Recuo }\end{array}$ \\
\hline Agricultura & 103,97 & 171,48 & 64,93 & 13,20 \\
\hline Corpos d'água & 653,66 & 567,37 & & \\
\hline $\begin{array}{l}\text { Campos Secos e } \\
\text { Campos Rochosos }\end{array}$ & 29,34 & 33,64 & 14,66 & \\
\hline Florestas & 108,84 & 143,33 & 31,69 & \\
\hline Edificações & 12,76 & 17,02 & 33,39 & \\
\hline Reflorestamento & 15,52 & 11,99 & & \\
\hline Campos Úmidos & 41,03 & 53,12 & 29,47 & \\
\hline $\begin{array}{l}\text { Pixels não } \\
\text { classificados }\end{array}$ & 59,51 & 26,68 & & \\
\hline Total & $\mathbf{1 0 2 4 , 6 3}$ & $\mathbf{1 0 2 4 , 6 3}$ & & \\
\hline
\end{tabular}

que são carregados pelas chuvas para os corpos de água, esses nutrientes dispostos na água e aliados aos meses mais quentes (verão), pode resultar em excessiva proliferação de algas e perda da qualidade da água. A Figura 04 apresenta a superfície do reservatório nos anos de 2001 e 2011. Isto evidencia que nesses locais pode ter ocorrido sensível diminuição do espelho d'água, indicando os locais de ocorrência de grande incidência de assoreamento. Em trabalhos recentes, Rocha \& Martins (2011) verificarm que macrófitas são muitos frequentes nesse local e se beneficiam com o assoreamento e a eutrofização, aumentando sua biomassa submersa, além disso, as três maiores colonizações de macrófitas foram registradas nas entradas dos principais tributários Pitangui e Jotuba.

(a)

(b)

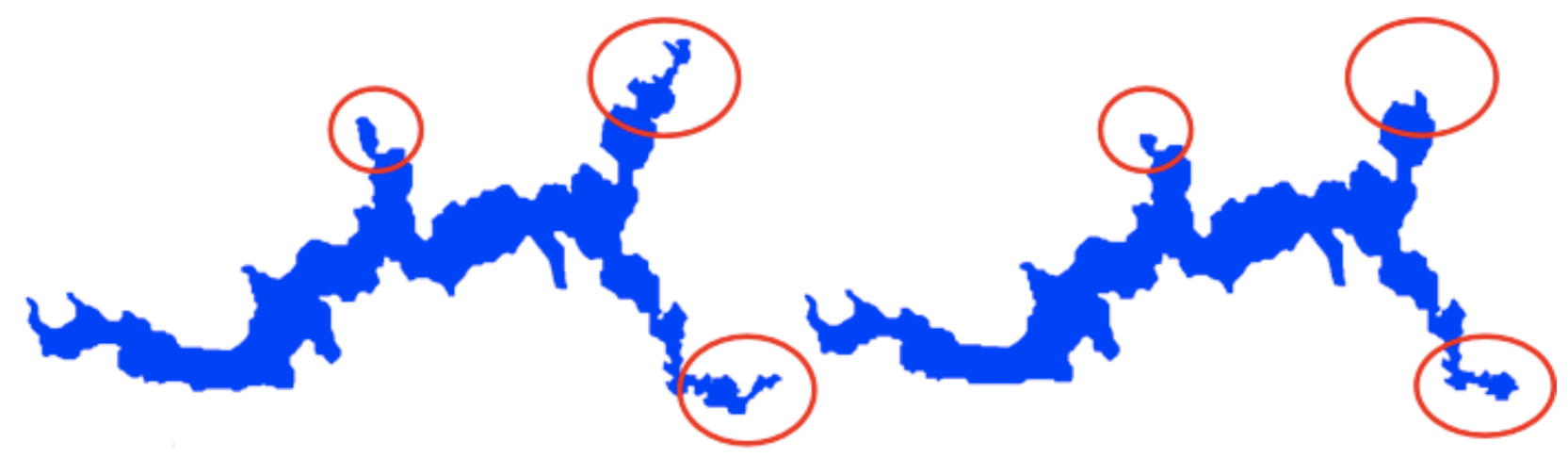

Figura 04. Superfície do reservatório de Alagados Ponta Grossa/Paraná para o ano de 2001 (a) e 2011 (b). 


\section{CONCLUSÃO}

O processo de classificação orientado ao objeto precedido da segmentação de imagens orbitais de resolução média permitiu uma análise multitemporal do uso e cobertura da superfície do reservatório da represa Alagados e de seu no entorno.

Uma faixa estreita de pixels pertencente à região de transição entre o espelho d'água do reservatório e às demais classes de uso e ocupação do entorno, não se enquadrou em nenhuma das classes pré-definidas, provavelmente em função da alta frequência espacial nessa faixa de transição, à baixa resolução das imagens em relação à largura desta faixa e também ao limiar de aceitabilidade definido na classificação.

Na faixa de 100 metros, específica de APP, no período de 2001 a 2011, foi detectado aumento para as classes "agricultura", "campos secos e campos rochosos", "florestas", "edificações" e "campos úmidos", e recuo nas classes "corpos d'água" e "reflorestamento".

O recuo nas áreas de corpos d'água em $13,43 \%$ (88,15 ha) demonstrando uma sensível diminuição na superfície do espelho d'água no período de 2001 a 2011 evidencia que nesses locais pode ter ocorrido sensível diminuição do espelho d'água, indicando os locais de ocorrência de grande incidência de assoreamento, porém, é possível que boa parte da diferença de espelho d'água detectada tenha ocorrido em função das diferenças de sazonalidade.

Os resultados apresentados permitiram verificar que a faixa de domínio de APP do entorno do reservatório Alagados, no município de Ponta Grossa, Paraná, vem sendo submetida a um processo de degradação devido principalmente a um aumento na ocupação por edificações e agricultura.

\section{REFERÊNCIAS BIBLIOGRÁFICAS}

ANDREOLI, C. V. Mananciais de Abastecimento: Planejamento e Gestão - Estudo de Caso do Altíssimo Iguaçu. Curitiba: SANEPAR Finep, 2003. 494p.

ANDREOLI, C. V. Manual para Elaboração de Plano de Manejo e Gestão de Bacia de Manancial. SPVS, Sanepar - 2ed. rev. - Curitiba, 1999. 184p.

BRASIL Meio Ambiente, Conselho Nacional do.
Resolução CONAMA 302 de 20 de Março de 2002. Disponível em < http://www.mma.gov.br/port/ conama/res02/res30202.html >. Acesso 27 de Maio de 2011.

BRASIL Meio Ambiente, Conselho Nacional do. Resolução CONAMA 303 de 20 de Março de 2002. Disponível em < http://www.mma.gov.br/port/ conama/res/res02/res30302.html >. Acesso em 27 de Maio 2011.

CÂMARA G.; SOUZA, R.C.M.; FREITAS, U.M.; GARRIDO, J. SPRING: Integrating remote sensing and GIS by object-oriented data modelling" Computers \& Graphics, 20: (3) 395-403, May-Jun 1996.

CROSTA, A. P. Processamento digital de imagens de Sensoriamento Remoto. Campinas: IG-UNICAMP,1992.

CRUZ, J. R; MATIAS, L. F. Geoprocessamento aplicado ao mapeamento dos impactos sociambientais decorrentes das formas de uso da terra nas Áreas de Preservação Permanente (APPs) da Represa de Salto Grande no município de Americana (SP). UNICAMP Geografia, Anais XIV Simpósio Brasileiro de Sensoriamento Remoto, Natal, 2009.

GALVÃO, F; AUGUSTIN, C. A ciência a serviço da sustentabilidade ambiental - as unidades fitoambientais como alternativa aos impasses do novo código florestal. Revista Floresta v. 41, n. 3, p. 667-678, 2011.

\section{GOULART, C. F. Diagnóstico e zoneamento} da Represa do Alagados. Ponta Grossa, 2001. Monografia (Especialização em Gestão Ambiental) NUCLEAM/UEPG. 51p.

Instituto Brasileiro de Geografia (IBGE). Manual Técnico da Vegetação Brasileira: Série Manuais Técnicos em Geociências. 1992. Rio de Janeiro, 92p.

Instituto Nacional de Pesquisas Espaciais (INPE). SPRING - Manuais - Tutorial de Geoprocessamento. São José dos Campos, 2006. Disponível em: < http://www.dpi.inpe.br/spring/ portugues/tutorial/classific.html $>$. Acesso em: 18 novembro de 2011.

MORO, J. C; COSTA, E. T. V; MILANESE, S; MORO, R. S. Evolução da cobertura vegetal nas 
áreas de preservação permanente na Represa de Alagados, PR. Monografia (Especialização em Gestão Ambiental) Universidade Estadual de Ponta Grossa. 36p.

MORO, J. C; COSTA, E. T. V; MILANESE, S; MORO, R. S. Comparação da cobertura vegetal nas áreas de preservação permanente na Represa de Alagados (PR), de 1980 a 2001. UEPG Ciência Biologia Saúde, Health Sci, Ponta Grossa, 2005.

OLIVEIRA, P. E; GOMES, A. R; SANCHES, R. C; SADD, A. R. Análise da evolução da paisagem no entorno da Represa dos Rios Jaguari e Jacareí, Estado de São Paulo, com base em Sensoriamento Remoto e SIG. UNESP Geociências, v. 27, n. 4, p. 527-539, 2008.

PARANÁ ITCG, Instituto de Terras, Cartografia e Geociências. Cartas Coloridas em escala 1:50.000. Ministério do Planejamento, Orçamento e Gestão - IBGE - Ministério da Defesa - Exército Brasileiro Departamento de Ciência e Tecnologia Diretoria de Serviços Geográfico - Região Sul do Brasil. Disponível em $<$ http://www.itcg.pr.gov.br $>$. Acesso em 20 de Maio 2011.

ROCHA, D. C; MARTINS, D. Levantamento de plantas daninhas aquáticas no reservatório de Alagados, Ponta Grossa - PR. Dep. de Biologia Geral, UEPG. Planta Daninhas, v. 29, n.2, Viçosa-MG, 2011, p. 237-246.

ROCHA, J. S. M. da. Manual de Projetos Ambientais. Imprensa Universitária, Santa Maria, 1997.

SILVA, A. M. da; SCHULZ, H. E; CAMARGO, P. B. Erosão e Hidrossedimentologia em Bacias Hidrográficas. ed RiMa - São Carlos - SP, 2003, 140p.

UEPG. NUCLEAM. Bacia hidrográfica do manancial Alagados. Ponta Grossa, 2002. (Relatório técnico) - CD-ROM.

ZAR, J. H. 1999. Biostatistical analysis. PrenticeHall, New Jarsey. 666p. 